\title{
REVISION OF THE INDO-PACIFIC SPHENOCARCINUS WITH A SINGLE ROSTRUM AND DESCRIPTION OF TWO NEW SPECIES (CRUSTACEA, DECAPODA, BRACHYURA, MAJIDAE)
}

\author{
by \\ D. GuINOT ${ }^{1}$ ) and B. RICHER DE FORGES ${ }^{2}$ )
}

\begin{abstract}
Two species of the genus Sphenocarcinus A. Milne Edwards 1876, with a single rostrum exist in the Indo-Pacific and they are principally only known by their original description: S. cuneus (Wood-Mason 1891) and S. aurorae Alcock 1899. Each species is herewith redescribed, based on the examination of the types. Two new species are established. S. difficilis sp. nov., represented by numerous specimens from Madagascar (ORSTOM collection), proved to be an intermediate species between $S$. cuneus and S. aurorae. S. pinocchio sp. nov., (collected in the Makassar Strait, Indonesia (mission Corindon II), is characterized by its very Jong and strongly curved rostrum. One male specimen, also collected in the Makassar Strait, probably modified by a sacculinid parasite, and with a more curved, snub rostrum, can be regarded as an unusual form of $S$. pinocchio sp. nov. A key of the four Indo-Pacific Sphenocarcinus with a single rostrum is presented.
\end{abstract}

\section{RESUME}

Le genre Sphenocarcinus A. Milne Edwards 1875 n'est connu dans I"Indo-Pacifique que par deux especes a rostre simple, principalement representees par la description originale: S. cuneus (Wood-Mason 1891) et S. aurorae Alcock 1899. Chacune de ces deux especes est iei redecrite et figuree d'apres l'examen de specimens types. Deux especes nouvelles sont decrites. S. difficilis sp. nov. etablie grace a un abondant materiel provenant de Madagascar (collection ORSTOM), apt>ariut comme intermediaire entre S. cuneus et S. mirorae. S. pinocchio sp. nov. du detroit de Makassar, rndonesie (mission Corindon IT) se distingue par un rostre tres allonge et fortement incurve; provenant egalement du detroit de Makassar, un individu male parasite par une Sacculine presente un rostre encore plus "retrousse" et ne pent pour Finstant qu'etre suppose representer une forme anormale de $S$. pinocchio. Une clef des quatre especes indo-pacifiques de Sphenocarcinus a rostre simple est proposee.

$\left.{ }^{1}\right)$ Museum national d'Histoire naturelle, Laboratoire de Zoologie, 61 rue de Buffon, F75231 Paris cedex 05, France.

${ }^{2}$ ) Office de la Recherche Scientifique et Technique Outre-Mer (ORSTOM), 24 rue Bayard, F77008 Paris, et Museum national d'Histoire naturelle, Laboratoire de Zoologie, 61 rue de Buffon, F'75231 Paris cedex OS, France. 


\section{INTRODUCTION}

While studying the Indonesian material we came across to several specimens from Madagascar that proved to be another new species. We thought therefore it would be necessary to reexamine all the species belonging to single-rostrum group of the Indo-Pacific Sphenocarcinus. Genus Sphenocarcinus A. Milne Edwards, 1875.

The genus Sphenocarcinus A. Milne Edwards (1875: pi. 17, fig. 5; 1878; 135) is represented by: 1) two American species: S. corrosus A. Milne Edwards 1875, the type-species, and S. agassizi Rathbun 1895, two "analogous species on opposite sides of the continent" (RATHBUN 1925: 187); both are characterized in having a rostrum formed of two long contiguous spines; 2) eleven Indo-Pacific species, into which we iiave just added three new species, which means that a total of 14 species are known from this area ( $c f$. GUINOT \& RICHER DE FORGES in press).

Regarding the Indo-Pacific Species, only two, very rare species, have a single rostrum: Sphenocarcinus cuneus (Wood-Masoii, 1891) and $S$. aurorae Alcock 1899; the rest of the Indo-Pacific species has a bifurcated rostruttn, with spines more or less long and divergent (we Notice that $S$. auritus Rathbun 1916, has a rostrum with two short flattened lobe's, separated [by a narrow silt (cf. GRIFFIN, 1976: 211, fig .10b). $S$. auneus is known by the original record's, from the Andaman Sea, and by two other records in the Western Indian Ocean (Providence I., Mombasa), $S$. aurorae is only known from the Travancore coast, first by the original report (ALCOCK 1899: 84), then by KEMP \& SEWELL (1912: 30); both were collected-by the "Investigator" in two different surveys.

The recent discovery of Indo-Pacific Sphenocarcinus with a single rostrum is therefore interesting. The type material of S. cunem and $S$. aurorae, deposited in the Zoological Survey of India, Calcutta, was made available through the kindness of Dr. Maya Deb, Curator of Crustacea in this Institution, which enables us to redescribe and figure these two nice-looking species. This examination also allowed us to describe as a new species, $S$. difficilis sp. nov., a Sphenocarcinus from Madagascar represented by numerous samples, which seems to be intermediate between $S$. cuneus and $S$. aurorae. On the other hand, the discovery of Sphenocarcinus in the Makassar Strait lead us to establish a new other species, 5. pinocchio sp. nov. In a station, 5. pinocchio (one holotype, two paratypes) has a very long ro,strum, especially in the male; in another station of Makassar Strait, a sacculinized male speci- 


\section{THE INDO-PACIFIC SPHENOCARCINUS}

men has a very curious curved rostrum: probably the sacculinid may have modified this individual, the rostrum has then becaime (? abnormally) feminized? A such supposition requires further confirmation.

Key to the Indo-Pacific species of Sphenocarcinus with a single Nostrum

Al. The single rostrum not extremely long neither very curved.

B1. Cardiac plate triangular, touching the gastric plate. Rostrum moderately long.

S. cuneus (Wo'od-Mason): Andaman Sea,

? Providence I., Mombasa.

B2. Cardiac plate not triangular, well separated from the gastric plate.

Cl. Rostrum very short, even in the male. All the plates widely separated; preocular plate with angular borders exter nally; cardiac plate heart-shaped S. aurorae Alcock: Travancore coast

C2. Rostrum long. Plates less widely .separated. Pfceocular plate with rounded angles. Cardiac plate transversely subcircular S. difficilis sp. nov.: Madagascar

A2. The single rostrum extremely long and curved in the male. Cardiac plate with postero-lateral expansions postero-lateral expansions S. pinocchio sp. nov.: Makassar Strait, Indonesia

Sphenocarcinus cuneus (Wood-Mason 1891)

(Figures 1A-D, 6 A-B; pi. I, figures A-B)

Oxypleurodon cuneus Wood-Mason, in: Wood-Mason \& Alcock, 1891: 261; Andaman Sea. 
Sphenocarcinus cuneus, Alcock,. 1895: 193. Alcock \& Anderson, 1896, Illust. "Invest.", pi. 21, figs. 1, la - Alcock 1899; 50; Andaman Sea - ? Rathbun 1911: 249; Providence I. - ? Griffin 1974: 29; E. of Mombasa.

\section{Material examined}

Andaman Sea, between N. and S. Sentinel Is,, sta. 56, 24-25-IV-1889, 'Investigator" Marine Survey: "type", ô 15 X $11 \mathrm{~mm}$ (rostrum only: $8 \mathrm{~mm}$ ) (Zoological Survey of India, Reg. $n^{\circ} 143-6 / 7,3186 / 9$ ).

\section{Remarks}

Sphenocarcinus cuneus (Wood-Mason) (in: WoOD-Mason \& AlCOCK 1891: 261) has been established for a sample containing two males and one ovigerous female, collected in the Andaman Sea (sta. 56, 220-240 fath.); a female individual (after tihe legend) is figured in Illustr. "Investigator" (ALCOCK \& ANDERSON 1896, pi. 21, figs. 1, la). AlCOCK (1895: 193; 1893: 50) described the species with more details, from the Andaman Sea (is it the same material ?) and indicated "161 to 250 fath."

We could examine a specimen indicated "type" from the Andaman Sea, a male measuring $15 \times 11 \mathrm{~mm}$ (rositrium only: $8 \mathrm{~mm}$ ). This male type (Fig. 1 A-D, pi. I, Figs. A-B) resembles very much the female figured in the Illustr. "Investig," (loc. cit.) in having the same disposition of the plates on the dorsal surface, as follows: an elongale-oval gastric plate; a triangular cardiac plate (Fig, ID), the anterior angle of which is touching the posterior border of the gastric plate; the preocular plate with the internal border salient (PL 1 fig. B) and with rounded angles; the branchial plate somewhat semilunar and very produced laterally. All the plates are strongly raised and separated by deep but not very wide channels. The surface of the plates is punctate, eadh puncture containing a very short spherical seta. The rostrum, of the male type seems to be a little longer than in the female of the Illustr. "Investig."; it is enlarged at its base and bears short setae; it is distinctly bifid at the tip. Some hook-shaped setae are present on the branchial lateral borders, on the gastric region (not on the gastric plate) and in the frontal basal region. A small tuft of hairs stands on each side of the cardiac plate. 




Figure 1. Sphenocarcimis cuneus (Wood-Mason), type, ô 15 X $11 \mathrm{~mm}$ (rostrum only: $8 \mathrm{~mm}$ ), Andaman Sea, "Investigator" Marine Survey (Zool. Survey India, Reg. 143-5/7, 3186/9): A, anterior region, dorsal surface: B. id., ventral surface; C, side face; D, cardiac plate on the dorsal surface. (All X 10). 
Alcock (ibid.) did not indicate the existence of variations in. the disposition of the plates of the three known individuals of $S$. cimeus; he noticed only that the rostrum is longer fn the males than in the female. The abundant material of the Sphenocarcinus collected at Madagascar shows to us the constancy of the characters (except the sexual dimorphism) in the species herewith described under the nafme S. difficilis sp. nov. (cf. infra). We, therefore, consider that S. cuneus is a species with a moderately long single rostrum, with a tria ngular cardiac plate nearly contiguous to the gastric plate; all the plates are separated by relatively not very wide channels.

Perhaps additional material will permit to verify all these characters and find other differences between $S$. cuneus, $S$. aurorae and $S$. difficilis sp. nov. (cf.infra), with the consideration of the presence oft the sexual dimorphism.

\section{Distribution}

Sphenocarcinus cuneus is known from the Andaman Sea where three (to be verified) specimens have been collected by the "Investigator". The reports from the Providence Island (Rathbun, loc. cit.) and from the East-African Coast (Mombasa: Griffin, loc. cit.) are questionable.

Sphenocarcinus aurorae Alcock 1899

(Figures 2 A-D; PL I figures C-D)

Sphenocarcinus aurarae Alcock, 1899: 84; off the Travancore coast: Kemp \& Sewell, 1912: 30, pi. 1, fig. 10; off the Travancore coast.

\section{Material examined}

Off the Travancore coast, Laccadive Sea, $8^{\circ} 37^{\prime} \mathrm{N}-75^{\circ} 52^{\prime} 30^{\prime \prime} \mathrm{E}$. "Investigator" Marine Survey, sta. 248, 17-X-1898, 224-284 fath.: "type", ovigerous $\circ 15.5 \times 13 \mathrm{~mm}$ (rostrum only: $5 \mathrm{~mm}$ ) (Zoological Survey of India, Reg. $\mathrm{n}^{\circ}$ 2874-2900/10).

\section{Remarks}

In the same work where fee provided an extensive description of Sphenocarcinus cuneus (Wood-Mason 1891), AlCOCK (1899: 50) gave an addendum where he established, without a sketch, an additional species (ibid.: 84) originating "from off the Travancore coast, 224-284 
fath.", S. aurorae, which closely resembles $S$. cuneus". Alcock had at his disposal 27 specimens of $S$. aurorae to compare with three specimens of $S$. cuneus and recognized several particulars separating the two species. Shortly after, KemP \& SEwEel (1912: 30, pi. 1, fig. 10) mentioned 12 males and 15 females collected by the "Investigator" during the survey season 1910-1911,, alt ,sta. 391, 9¹4'10"N $-75^{\circ} 45^{\prime} \mathrm{E}, 260$ fath. (about the same area than Alcock and the same number of specimens) and gave a drawing of a male S. aurorae. S. uarorae has not been hitherto reported.
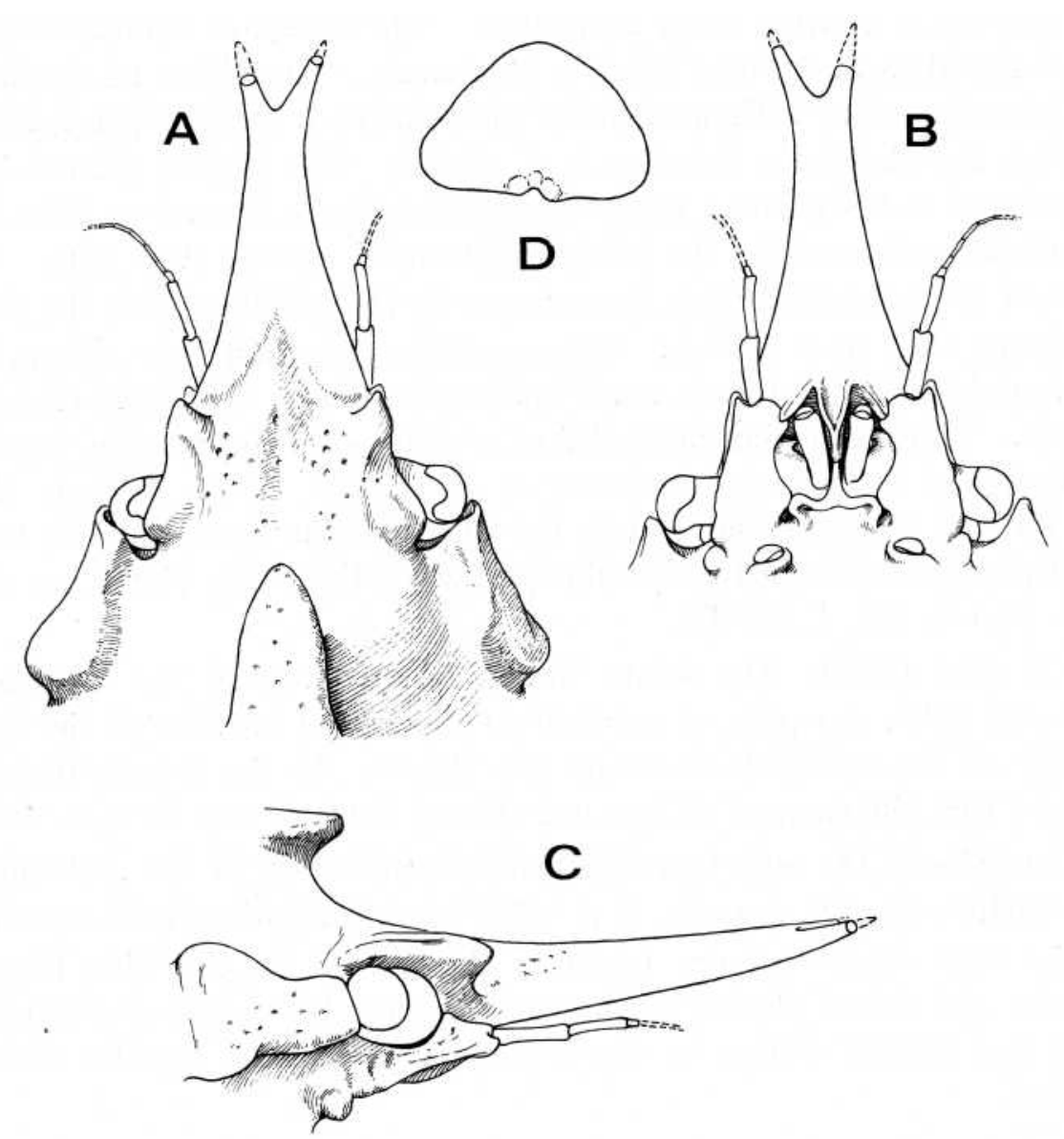

Figure 2. Sphenocarcinus aurorae Alcock, "type", ovigerous $q$ 15,5 X $5 \mathrm{~mm}$ (rostrum only: $5 \mathrm{~mm}$ ), sta. 248, 224-284 fath. (Zool. Survey India, Reg. 2874-2900/10): A, anterior region, ventral surface: B, id., ventral surface; C, side face; D, cardiae plate on the dorsal surface. (All X 8.5). 
We could examine one specimen of the original Indian 'material indicated "type", an ovigerous female measuring 15.5 x $13 \mathrm{~mm}$ (rostrum only: $5 \mathrm{~mm}$ ). This female apparently is identical by all characters with the male illustrated by KEMP \& SEWELL. We believe that $S$. aurorae is a valid species. We are able to compare it with $S$. cuneus, also- one of the types, a male (cf. supra, Fig. 1 A-D, PL I figs. A-B). In S. aurorae (Fig. 2 A-D, PI. 1 figs. C-D) the length of the single rostrum, distincly bifid at the tip is more related in the male than in the female (relatively shorter in the female for both species); in the female type the rostrum is swollen in its basal part. The carapace is more enlarged and inflated in $S$. aurorae than in S. cuneus: The plates on the dorsal surface are smaller with much wider channels in $S$. aurorae (PL I, fig. C), whereas the plates are close-set in S. cuneus. The cardiac plate is heart shaped and well separated from the gastric plate in S. aurorae (Fig. 2D), triangular and touching the gastric plate in $S$. cuneus (Fig. ID). In $S$. aurorae, the branchial plate is narrower in the middle and in the lateral expansion than in $S$. cuneus. The preocular plate, not very salient, ends sub-acutely and therefore is much more spine-like in $S$. aurorae than in $S$. cuneus. The postocular plate offers a wide posterior margin, extended internally in S. aurorae, narrower in $S$. cuneus. In $S$. aurorae (PL I fig. D), the pterygostomial plate has an irregular border and is widely separated from the postocular plate, whereas these two plates are closer in $S$. cuneus (PL I fig. B).

AlCOCK (1899: 84) wrote about $S$. aurorae that "as regards the male sex only: the pair of carinae on the dorsal surface of the carpopodites of the chelipeds and legs are blunt". In the female types, we observe that the carinae of legs are strong, more or leas as in S. cuneus.

In spite of the only two specimens exattnined by us for each species, we conclude that $S$. aurorae is a valid species, characterized especially: by the very short rostrum (even in the male) ; by the wide channels between the raised plates; by the cardiac plate heart-shaped and remote from the gastric plate; by the preocular plate with angular external borders.

\section{Distribution}

Known only from the coast of Travancore. 


\section{THE 1ND0-PACIF1C SPHENOCARC1NUS}

Sphenocardnus difficilis sp. nov.

(Figures 3 A-D; PI. I figures E-H)

\section{Material examined}

\section{1) Type material}

Madagascar, chalutage $123,12^{\mathrm{C}} 41^{\prime} 7 " \mathrm{~S}-48^{\circ} 14^{\prime} 5^{\prime \prime} \mathrm{E}, 310-315 \mathrm{~m}$, Crosnier coll., ll Octobre 1974: holotype, ô 18.5 x $19.5 \mathrm{~mm}$ (MP-B8819), paratype, ô $27 \times 17.5 \mathrm{~mm}, 3$ paratype ㅇ $24 \times 16 \mathrm{~mm}(2 \mathrm{spec}), 21.5 \mathrm{x}$ $15.5 \mathrm{~mm}$ (ovigerous females) (MP-B7977).

\section{2) Other paratypes}

Madagascar, chalutage $1,12^{\circ} 52^{\prime} \mathrm{S}-48^{\circ} 10^{\prime} 3^{\prime \prime} \mathrm{E}, 420-428 \mathrm{~m}$, Crosnier coll., 4 March 1971: 1 त 12 x 9 mm (MP-B7976).

Madagascar, chalutage 3, $12^{\circ} 52^{\prime} 3^{\prime \prime S}-48^{\circ} 10^{\prime} 4 " \mathrm{E}, 415-403 \mathrm{~m}$, Crosnier coll, 4 March 1971; 2 o $12 \times 8.5 \mathrm{~mm}, 10 \times 8 \mathrm{~mm}, 3$ ㅇ $17 \times 12 \mathrm{~mm}$, $15.5 \times 12 \mathrm{~mm}, 13.5 \times 10.2 \mathrm{~mm}, 12$ ovig. $17.5 \times 13 \mathrm{~mm}$ (MP-B7975).

Madagascar, chalutage 6, $12^{\circ} 42^{\prime} 7 " \mathrm{~S}-48^{\circ} 12^{\prime} 8^{\prime \prime} \mathrm{E}, 444-435 \mathrm{~m}$, Crosnier coll., 4 March 1971: 1 ㅇ 18 x $12 \mathrm{~mm}$ (MP-B7973).

Madagascar, chalutage $10,12^{\circ} 43^{\prime} \mathrm{S}-48^{\circ} 15^{\prime} \mathrm{E}, 300-348 \mathrm{~m}$, Crosnier coll. 14 April 1971: 1 đ juv. 8.2 x $6.1 \mathrm{~mm}, 1$ 우 21.5 x $15 \mathrm{~mm}$ (MPB7969).

Madagascar, chalutage $11,12^{\circ} 39^{\prime} 8^{\prime \prime} \mathrm{S}-48^{\circ} 15^{\prime} 2^{\prime \prime} \mathrm{E}, 375-385 \mathrm{~m}$. Crosnier coll., 14 April 1971: 1 q ovig. 20 x 13 mm (MP-7974).

Madagascar, chalutage 13, 12 ${ }^{\circ} 41^{\prime} 3^{\prime \prime} \mathrm{S}-48^{\circ} 16^{\prime} \mathrm{E}, 308-314 \mathrm{~m}$, Crosnier coll., 15 April 1971: 1 \& 19 x $14 \mathrm{~mm}$ (MP-B7971).

Madagascar, chalutage $28,12^{\circ} 42^{\prime} 9^{\prime \prime} \mathrm{S}-48^{\circ} 12^{\prime} 1 " \mathrm{~S}, 445-455 \mathrm{~m}$, Crosnier coll., 12 September 1972: 1 त 18 x 12 mm (MP-B7972).

Madagascar, chalutage 40, 12०46'4"S - 48 ${ }^{\circ} 11^{\prime} 5^{\prime \prime E}, 405-410 \mathrm{~m}$, Crosnier coll., 15 September 1972: 1 \& 24 x 16.5 mm, (MP-B7970).

\section{Description}

Carapage elongate subpentagonal. A long tapering cylindrical single rostrum, longer in the adult male (PL I figs. E-F) than in the female (P1. I fig. G) and in the juvenile (PI. I fig. II), emarginate at the tip and not curved (PI. I fig. F). Dorsal surface symmetrically ornamented with raised punctate islets, separated by moderately wide channels; these channels covered with short setae; some hook-shaped setae on the postero-lateral borders, on the anterior gastric regions and 
on the base of the rostrum. The raised plates as follows: one elongateoval on the gastric region; one transversely isubcircular on the cardiac region, very well separated from the gastric plate and sometimes with a tubercle on each side; this cardiac plate never with lattero-posterior expansions (Fig. 3D); one (intestinal) in the shape of a Cupid's bow along the posterior border one on the branchial region, wide and extending laterally; one postocular plate (fused with the hepatic plate) a little wider at its base; a preocular plate not very raised but flattened and with rounded angles (except in so'me juveniles where it ends subacutely: P1. I fig. $\mathrm{H}$ ); one elongate plate on the subbranchial region; a pterygostomial plate moderately separated from the postocular plate ( $\mathrm{Pl}$. I Fig. F).

Antennular and antennal region: Fig. 3B.

Sternum plate setose, deeply channeled.

Male abdomen with seven segments.

Chelipeds stouter in the male (P1. I fig. E) than in the female (P1. I fig. G), smooth: the carpus with a double cerst.

Ambulatory legs cylindrical, shorter and more carinated in the male than in the female; the merus more widened and more crested in the female.

\section{Remarks}

The preliminary identification of the material and the first glance suggested that this material <of Madagascar would be Sphenocarcinus cuneus (Wood-Mason). The comparison of the numerous Madagascar specimens with the figure in the Illustr. "Investig." (1896, pi. 21, figs. 1 , la), and then with a male type of $S$. cuneus and with a female type of S. aurorae Alcock showed several differences: we found necessary to establish a new species, $S$. difficilis sp. nov. The encountered difficulties were compensated by the fine and various material collected by A. Crosnier in the north of Madagascar.

Through the examination of these numerous samples from Madagascar we are able to present the following remarks about the variations within the species.

In some male juveniles the rostrum; is extremely short and thick, pubescent, namely of the female type, and even it can show a base very enlarged, with a deeply bifid (PL I fig. $\mathrm{H}$ : ${ }^{\wedge} 8.2 \times 6.1 \mathrm{~mm}$, chalutage 


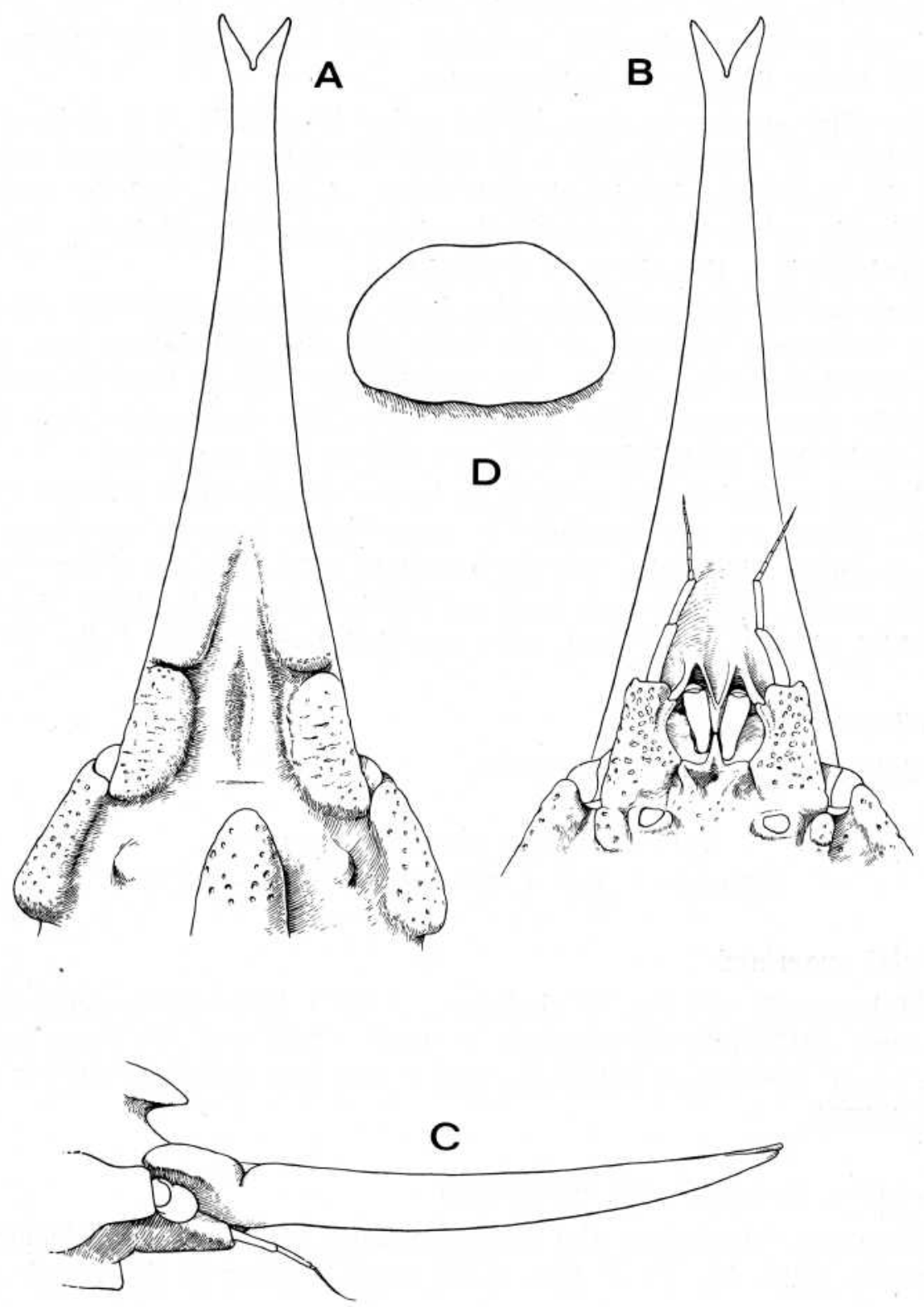

Figure 3. Sphenooarcmus difficilis sp. nov., holotype, o 28.5 X $19.5 \mathrm{~mm}$, Madagascar, $12^{\circ} 41^{\prime} 7 " \mathrm{~S}-48^{\circ} 14^{\prime} 5^{\prime \prime E}$, chatulage 123, 310-315 m (MP-B8819): A, anterior part, dorsal surface; B, id., ventral surface; C, side face; D, cardiac plate on the dorsal surface. (All X 6). 
10). In the same male juveniles with a very short rostrum, the plates are spaced by much wider channels and the preocular plate ends su-bacutely with a little spine-like anterior process, as ALCOCK $(1899 ; 84)$ pointed it for $S$. aurorae of larger .size.

In other specimens, even in the males (especially in a male of the "chalutage" 28 measuring $18 \times 12 \mathrm{~mm}$ ) the plates on the dorsal surface have the punctures furnished with short, close setae and the rostrum is distinctly pubescent; generally the plates seem to be glabrous, smooth, but perhaps it is the effect of a brushing.

Summarily, the male juveniles have a rostrum relatively shorter, thick, sometimes widened at the base, and the ambulatory legs more carinated than in the adults. The females (PL I fig. G) have the rostrum distinctly shorter and wider than the males, the plates punctated, often pubescent; their ambulatory legs are shorter and carinated.

In our material, the uniformity in. the arrangement and the shape of the plates on the carapace is remarkable (except sometimes the channels more widened). The cardiac plate (Fig. 3D) are always transversely oval - shaped and does not touch the gastric plate; the subbranchial plate is prominent, with rounded borders (PI. T fig. F).

\section{Distribution}

Only known from Madagascar.

$$
\text { Sphenocatnrwiois pinocehio }{ }^{1} \text { ) sp, nov. }
$$

(Figures 4 A-D, 6 EF; P1. II figures A-D)

\section{Material examined}

Makassar Strait, sta. 267, holotype, o 38 x $15.5 \mathrm{~mm}$ (rostrum only), $23.5 \mathrm{~mm}$ ) (MP-B8749) ; paratype $\curvearrowright 11.5 \mathrm{x} 11,5 \mathrm{~mm}$ (rostrum broken at its base), paratype o ovigerous $19.5 \times 11.5 \mathrm{~mm}$ (rostrum only: $11 \mathrm{~mm}$ (MP-B8750).

\section{Description (holotype and paratypes)}

Carapace triangular: the single rostrum very long and slender in the males, (Fig. 4A, PL II figs. A-B) much shorter in the female (Pl.

$\left.{ }^{1}\right)$. The specific name is referred to Pinocchio, the hero of a child's book written by the Italian writer Collodi from the 19th century: the long and "turned-up" rostrum of this species recall to mind the long and snub nose of the mischievious Pinocchio. 


\section{THE INDO-PACIFIC SPHENOCARCINUS}

II figs. C-D), and with an extremely deeply bifid in the males, only emarginate in the female (to be verified); the rostrum much more incurved in the males (Fig. 4C, PL II fig. B) than in the female (PL II fig. D).

Dorsal surface (PL II figs. A, C) with several raised islets or plates arranged as follows: one elongate-oval and not very large on the gastric region; a single and elongate branchial plate, the external part extending laterally behind the line of the carapace; one pentagonal plate on the cardiae region (Fig. 4D), with an anterior border truncate and with two characteristic expansions on each side of the hinder part in the males as in the female; one plate in the shape of a Cupid's bow along the posterior border; one postocular-hepatic plate, narrower in the part close to the eye than in the basal part: a preocular plate not very prominent (Fig, 4A) ; a narrow plate on the postero-lateral border; below, a subbranchial plate which is small and not very prominent (PI. II figs. B, D); a plate on the pterygostomial region small, with an irregular shape and an eroded aspect.

Surface of the plates punctate, without; setae (but the specimens perhaps have been brushed); the punctures much well-marked in the female. The surface between the plates almost glabrous (? brushed) except in the place of the hooked setae which are located on the external side of the branchial plate, on the anterior gastric region and along the rostrum in the basal part.

Rostrum with small, short and triangular setae, mare numerous in the female (PL II figs, C-D), diminishing on the distal part in the males (PL II, figs. A-B) ; on the bifid extremity, setae a little longer (Fig. 4A).

Orbito-antennal region: Fig. 4B.

Sternal plate clothed with a short, close tomen.tu.in and deeply channeled by grooves, especially along the sutural lines. Male aparture coxal.

Male abdomen with seven somites.

Chelipeds stout in the males (P1. II fig. A), smooth and unarmed; only some punctures; margins of the triangular merus blunt; carpus with two blunt crests above. Fingers elongate, meeting only at the tips. In the female, chelipeds slender, weaker and pubescent; merus carinated especially on tihe upper border.

Ambulatory legs with a strong sexual dimorphism: in the males (P1. II fig. A) elongate and cylindrical, except the carpus which is 


\section{GUINOT AND B. RICHER DE FORGES}

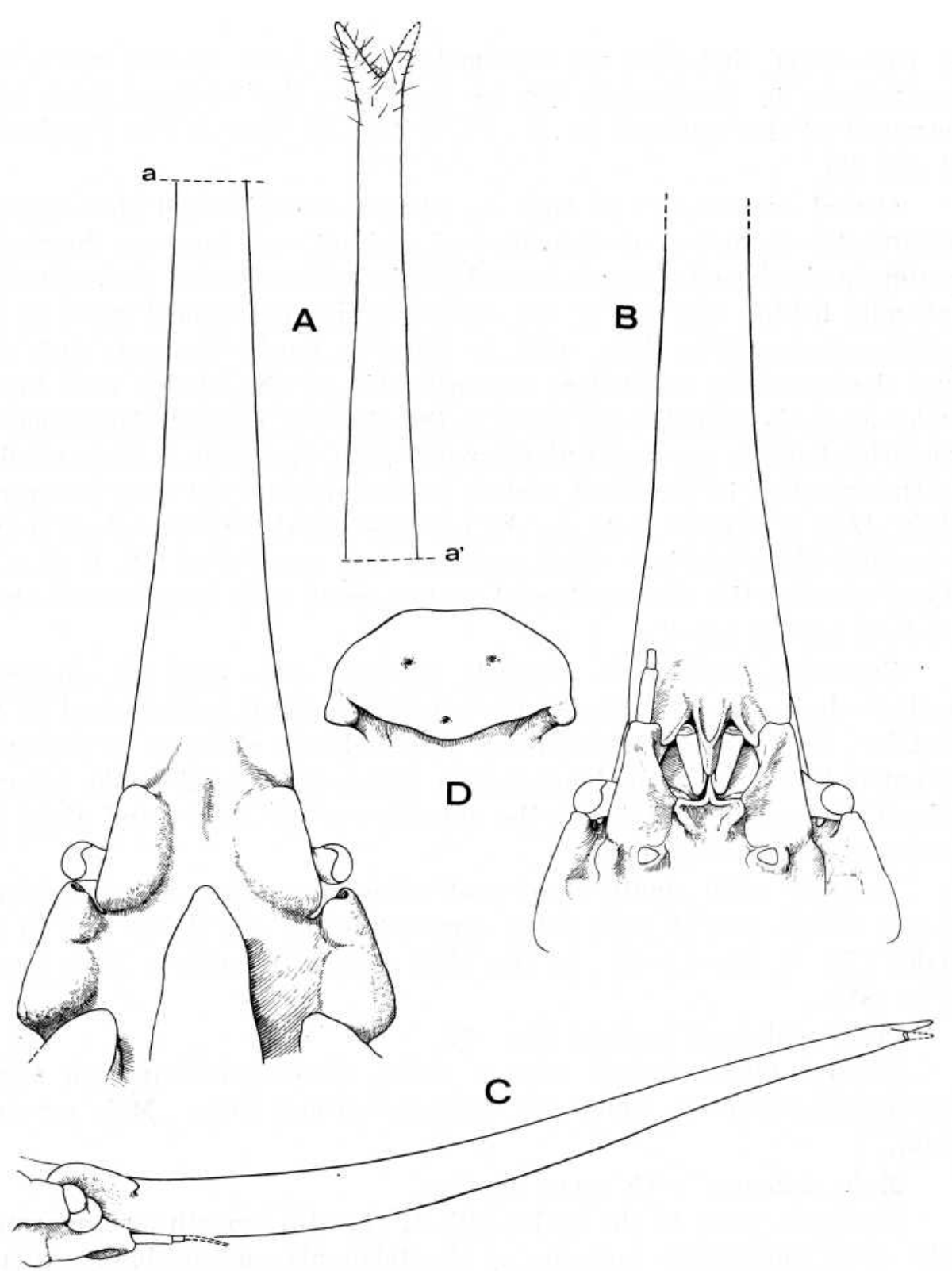

Figure 4. Sphenocarcinus pinocchio sp. nov., holotype, of $38 \times 15.5 \mathrm{~mm}$ (rostrum only: $23.5 \mathrm{~mm}$ ), Makassar Strait, sta. 267 (MP-B8749): A, anterior region, dorsal surface, with the very long rostrum drawed in two parts (a' continues a) $(\times 6)$; B, id., ventral surface $(\times 6) \quad C$, side face $(\times 4)$; $D$, cardiac plate on the ventral surface, with the characteristic lateral expansions $(\times 6)$. 


\section{THE INDO-PACIFIC SPHENOCARCINUS}

bluntly carinated and flattened. P4 and P5 shorter, with the merus reduced and faintly carinated. In the female (PI. II fig. C), ambulatory legs much shorter, with all the articles (except the dactylus) wide and thick; merus strongly carinated on p2-p5, the paired carinae on the carpus more pronounced than in, the 'males.

\section{Remarks}

There are now three known Indo-Pacific species of the genus Sphenocarcinus with a single rostrum: S. cuneus (Wood-Mason 1891), S. aurorae Alcock, 1899, and a new .species \&. difficilis, which has close recemblances with the two preceeding species. From $S$, difficilis, to which are assigned numerous samples from Madagascar (cf. supra, Fig. 3 A-D, Pl. I figs. E-H), S. pinocchio differs in several .seemingly constant characters whioh in our opinion necessitate the recognition of a new species. S. pinocchio differs from S. difficilis mainly in the following characters :

1) the rostrum is relatively much longer and also more curved in S. pinocchio (Fig. 4A-C, PL II figs. A-B) than in S. difficilis (Fig. 3 A-C, PL I figs. E-H), these two characters being less marked in the female of both species (S. pinocchio 5 : PL II figs. C, D; S. difficilis $\circ$ : Pl. I fig. G);

2) the cardiac plate has two latero-external expansions in C. pinocchio (Fig. 4D); it is subcircular and without lateral expansion in $S$. difficilis (Fig. 3D), where there is sometimes a tubercle on each part of this plate but always well separated.

3) the latero-posterior plate, situated ventrally below the branchial plate, is oval, distinctly prominent, with regularly, rounded borders in $S$. difficilis (Pl. I fig. F), narrow and with an eroded aspect in $S$. pinoc chio (PL II figs. B, D);

4) the postocular-hepatic plate (a single plate) is more prominent laterally, at least in the male, in $S$. difficilis (Fig. 3A, P1. I figs E, H) than in $S$. pinocchio (Fig. 4A, PL II figs. A, C);

5) the basal antennal article, with a longitudinal groove in $S$. pinoc chio (Fig. 4B), without a groove in S. difficilis (Fig. 3B).

The fir\&t male pleofpod is more or less similar in 'both species ( $S$. difficilis; Fig. 6 A-B; \&. pinocchio: Fig. 6 C-D).

The ohelipeds are about the same in both species (S. pinocchio: PL II fig. A; S. difficilis, PL I fig. E). A strong sexual dimorphism affects the ambulatory legs of $S$. pinocchio: the legs are shorter and 
more car mated in the female (PI. II fig. C) than in the male (PL II fig. A), perhaps more than in $S$. difficilis (Pl. I figs. E-G) (to be verified).

We wish that these differences could be further verified on a more complete material especially that of $S$. pinocchio. Anyway of the significant characters of $S$. aurorae Alcock are better known, we can with certainty compare $S$. aurorae to $S$. pinocchio sp. nov.. S. aurorae (cf. supra, Fig. 2 A-B, PL I figs. C-D) can be immediately distinguished by the short rostrum even in the adult male with stout chelipeds, as opposed to the very long rostrum of $S$. pinocchio sp. nov.

\section{Description of a saccidmized male individual with a well curved rostrum ("turned-up rostrum)}

(Figures 5 A-C: PL II figures E-F)

A single specimen (MP-B8751) collected in the Makassar Strait at the station 273 shows a particular character of the rostrum which is extremely curved (Fig. 5 A-C, PL II figs. E-F). It is a male carrying a Sacculina sp. under the abdomen: it measures $27 \times 15 \mathrm{~mm}$, the length of the rostrum being about $15 \mathrm{~mm}$; several balanids are attached to the carapace.

In several rtespects, this individual resembles greatly S. pinocchio sp. nov., especially in the arrangement of the plates, but differs in:

1) the rostrum (Fig. 5C: PL II fig. F), relatively shortter and much more .curved than in the male holotype of $S$. pinocchio wfaiah is about of the same size (Fig. 4 A-C; PL II figs. A-B); in both species, the rostrum lias the tip weakly bifid;

3 ) the ambulatory legs (PL II fig. E) less cylindrical and with articles more carinated than in the male holotype of 5. pinocchio ( $\mathrm{Pl}$. II fig. A); on the other hand, the chelipeds are stout and thick, analogous to those of the male holotype of S. pinocchio.

Only one individual being at our dispesal, moreover infected with a Sacculina sp., we question the value of these peculiarities. The ambulatory legs (PL II fig. E) are of the female type (P1. II fig. C), namely shorter and carinated: we can suppose that they became fominized. The chelipeds, completely developed, have the normal male type; the pleopods are present but both are broken at the place where the Sacculina's 


\section{THE INDO-PACIFIC SPHENOCARCINUS}

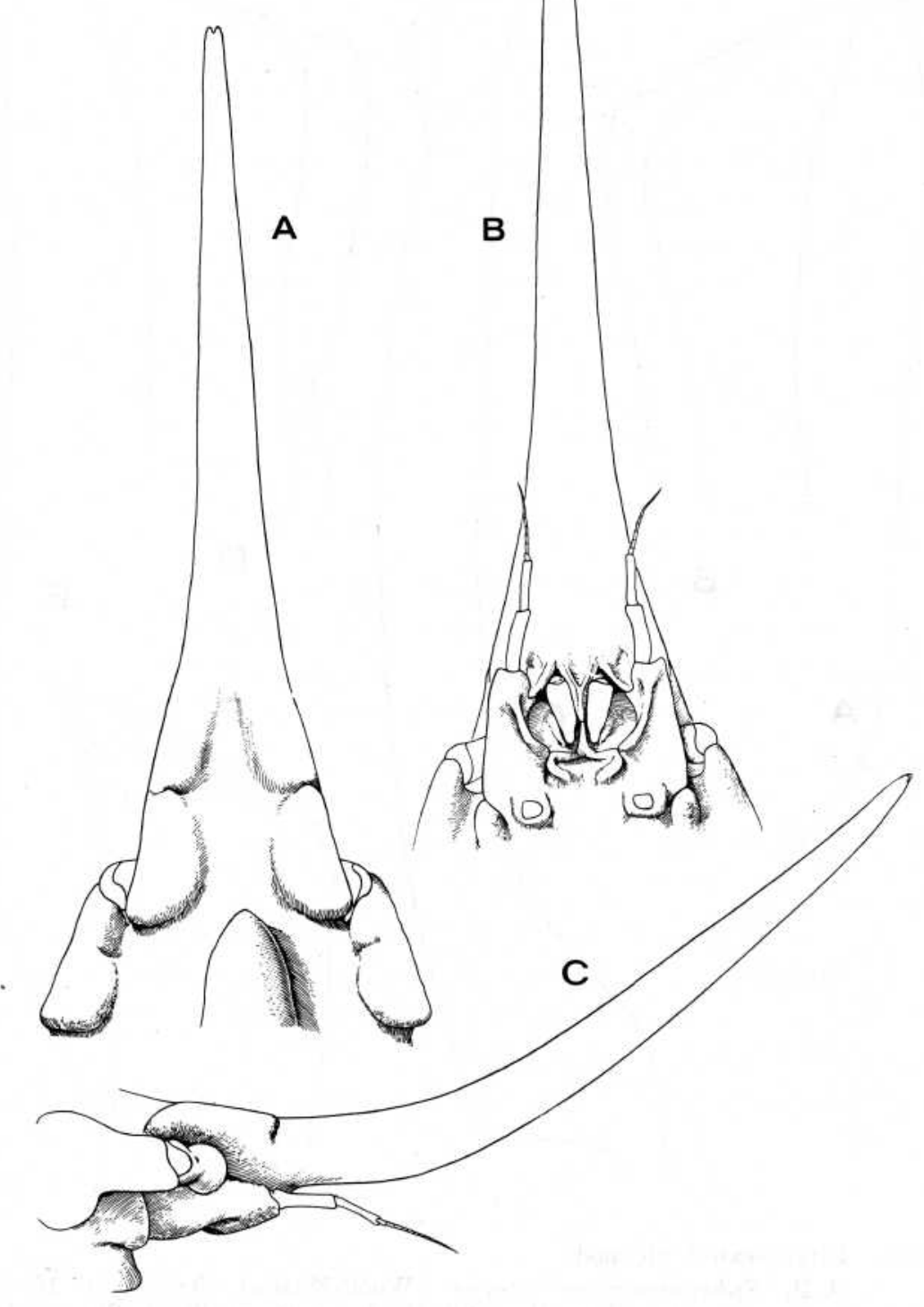

Figure 5. Sphenocarcinus pinocchio sp. nov., ? abnormal specimen with a sacculinid parasite, of $17 \times 15 \mathrm{~mm}$ (rostrum only, very curved: $15 \mathrm{~mm}$ ), Makassar Strait, sta. 273 (MP-B8751) : A, anterior region, dorsal surface; B, id., ventral surface; C, side face with the extremely "turned-up" rostrum $($ All $\times 6.5)$. 
D. GUINOT AND B. RICHER DE FORGES

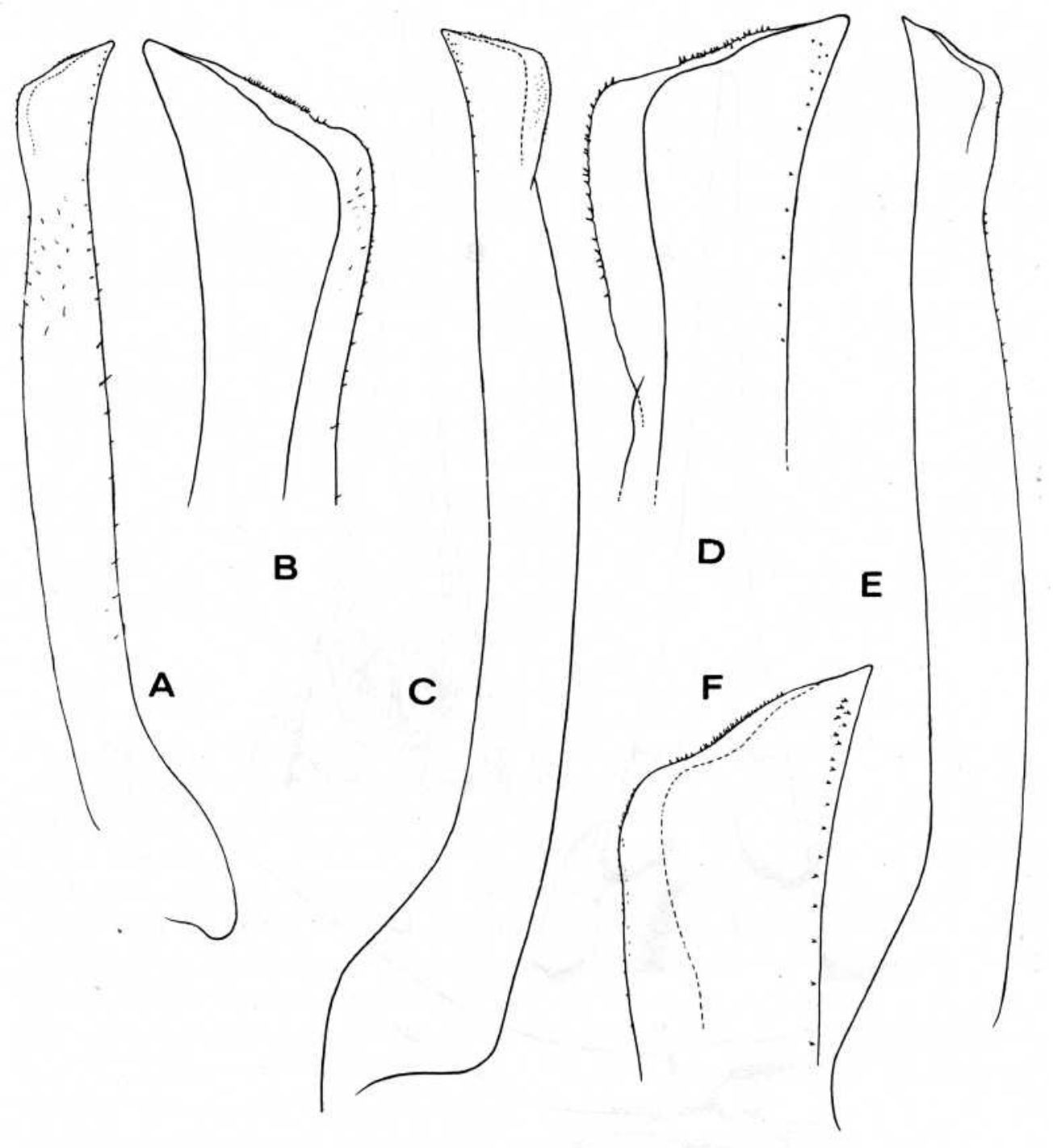

Figure 6. First sexual pleopod.

A-B, Sphenocarcinus cuneus (Wood-Mason), "type", of $15 \times 11 \mathrm{~mm}$, Andaman Sea, "Investigator" Marine Survey (Zool. Survey India, Reg. $143-5 / 7,3186 / 9): A$, pl I $(\times 42) ; B, i d$, apex $(\times 102)$.

chalutage 123, Crosnier coll. (MP-B8819): C, pl. I $(\times 33)$; D, id., apex $(\times 85)$.

C-D, S. difficilis sp. nov., holotype, ô $28.5 \times 19.5 \mathrm{~mm}$, Madagascar, sta. 267 (MP-B8749): E, pl. 1 ( $\times 33) ;$ F, id., apex $(\times 85)$. 


\section{THE INDO-PACIFIC SPHENOCARCINUS}

sac forms a wide knob under the abdomen and turns out the pleopods from the sterno-abdominal cavity. It seems that is it neither feminization of the chelipeds nor of the pleopods.

The question is whether the rostrum, as the ambulatory legs, could be feminized: that would explain the shortened rostrum, with a tip less bifid? The pronounced curvature (PL II fig. F) could be the result of an "abnormal" transformation because of the infection by a parasite, inasmuch as the rostrum of the male holotype of $S$. pinocchio (Fig. $4 \mathrm{~A}-\mathrm{C}$, PL II figs. A, B) is longer and more curved than in the female paratype (PL II figs. C, D).

We are very interested by the shape of the cardiac plate of the male individual parasitized with Sacculina sp. having a similar form to that of the non parasitized $S$. pinocchio (Fig. 4D, PL II figs. A, C), namely in the expansion on each side at the base of the plate.

For lack of material and furthermore the fact that the single specimen bears a parasite which produces probably a feminization, we leave it in $S$. pinocchio sp. nov. It was collected more or less in the same locality with other specimens of $S$. pinocchio, and in similar depths.

\section{ACKNOWLEDGEMENTS}

We are indebted to Prof. J. Forest and P. Le Loeuff, members of the Mission Corindon II who forwarded the valuable crabs of the Makassar Strait and to M. A. Crosnnier who has collected the numerous specimens from Madagascar.

We thank: Dr. Maya Deb, Curator of Crustacea at the Zoological Survey of India, Calcutta, who has 'kindly provided the "types" of $S$. cuneus and S. auirorae deposited in this Institution: Dr. R. B, Manning, Curator of Crustacea in the National Museum of Natural HistoryWashington, who loaned the 'material of Sphenocarcinus deposited in the Smithsonian Institution.

We gratefully appreciate the assistance of our collegue, Dr. Mohammad Kasim Moosa, for preparing the text in english and making several helpful comments.

Special thanks are extended to four staff members of the "Laboratoire -de Zoologie (Arthropodes), -Museum national d'Histoire naturelle", Paris: Josette Semblat for help in cheeking the bibliography and in the preparation of the manuscript; Maurice Gaillard for the execution of the original drawings Jacques Rebiere and Michele Bertoncini, our patient photographers. 


\section{GUINOT AND B. RICHER DE FORGES}

\section{REFERENCES}

Alcock, A. 1895. Materials for a Carcinological Fauna of India. No. 1. The Brachyura Oxyrhyncha. J. Asiat. Soc. Beng., 64 (2): 157 -191.

Alcock, A. 1899. An Account of the Deep Sea Brachyura collected by the Royal Indian Marine Survey Ship "Investigator", (Calcutta: 85 pp.

Alcock, A. and A.R.S. Anderson 1896. Crustacea. Part IV. Illustration of the Zoology of the Royal Indian Marine Surveying Steamer Ilnvestigator, pls. 16-07.

Griffin, DJ.G. 1974. Spider Crabs (Crusffeaeea; Brachyura; Majidae) from the International Indian Ocean Expedition, 1963-1964. Smithson. Contrib. Zool., (182); MV, 1-3-5, figs. 1-8, tabs. 1-6.

GRIFFIN, D.J.G. 1976. Spider Crabs of the family Majidae (Crustacea: Brachyura) from the Philippine Islands. Jourm. not. hist. 10': 179-2122.

Guinot, D. and B. RiChER DE Forges (in press). Majidae bathyaux des Philippines. In: Result, camp\&gnes MUSORSITOM. Mem. Or\&tom.

Kemp, S. and R.B.S. Sewell 19121. Notes on Deeapoda in the Indian Museum, III. The species obtained by R. I. M. S. S. "Investigator" during the Survey Season 1910-11. Rec. Indian Mus.9 7, pt 1 (2): 26-32.

MiLne-EDWARDS, A. 1813-1881.Etudes sur les Xvphosures et les Crustiaces de la region mexicaine. In: Miss, saient. an Mexique et dans VAmer. Centr., Rech. Zool. Faune Amer. Centr. et Mexique, part 5, vol. 1. Paris, imprimerie Nationale: 1-368 [for the dates of the publication, $c f$. Th. Monod. 1956: 642].

Rathbun, M.J. 1911. Marine Brachyura. In: The Percy Sladen Trust Expedition to the Indian Ocean in 1905' under the Leadership of Mr, J. Stanley Gardiner,

. Vol. III. No. XI. Trans. Linn. Soc. Lond. (2), Zool. 14 (2): 191-261, pi. 15-20.

Rathbun, M.J. 1916. New species of icrabs of the families Inachidae and Parthenopidae. In; Scientific results of the Philippine cruise of the Fisheries Steamer "Albatross", 1907-1910. — No. 34. Proc. U.S. nat. Mus., 50 (2135): 527-559.

Rathbun M.J. 1925. The Spider Crabs of America. Bull. U.S. natn. Mus. (129): I$\mathrm{XX}+1-613$.

Wood-Mason, J. and A. Alcock 1891. Notes on the Results of the last Season's Deep sea Dredging. Natural History Notes from H. M. Indian Marine Survey Steamer "Investigator" No. 21. Ann. Mag. nat. Hist. (6) 7: 258-272. 


\section{THE INDO-PACIFIC SPHENOCARCINUS}

\section{Plate I}

Figure A-B. Sphenocarcinus cuneus (Wood-Mason), "type", ô $15 \times 11 \mathrm{~mm}$, Andaman Sea, sta. 56, "Investigator" (Zool. Survey India no. 143-5/7, $3186 / 9)$ : A, entire animal; $B$, side face.

Figure C-D. S. aurorae Alcock, "type", ovigerous $q 15.5 \times 13 \mathrm{~mm}$, off the Travancore coast, Laccadive Sea, sta. 248, "Investigator" (Zool. Survey India no. 2874-2900/10): C, entire animal; D. side face.

Figure E-H. S. difficilis sp. nov.

E-F holotype, of $28.5 \times 19.5 \mathrm{~mm}$, Madagascar, chalutage 123 (MPB8819): E. entire animal; $F$, side face.

G, paratype, $\& 24 \times 16 \mathrm{~mm}$, Madagascar, chalutage 123 (MP-B7977): dorsal surface; the rostrum is shorter than in the male.

$\mathrm{H}$, paratype, of juv. $8.2 \times 6.1 \mathrm{~mm}$, Madagascar, chalutage 10 (MP. B7969): dorsal surface; at this size, the rostrum is very short in the male.

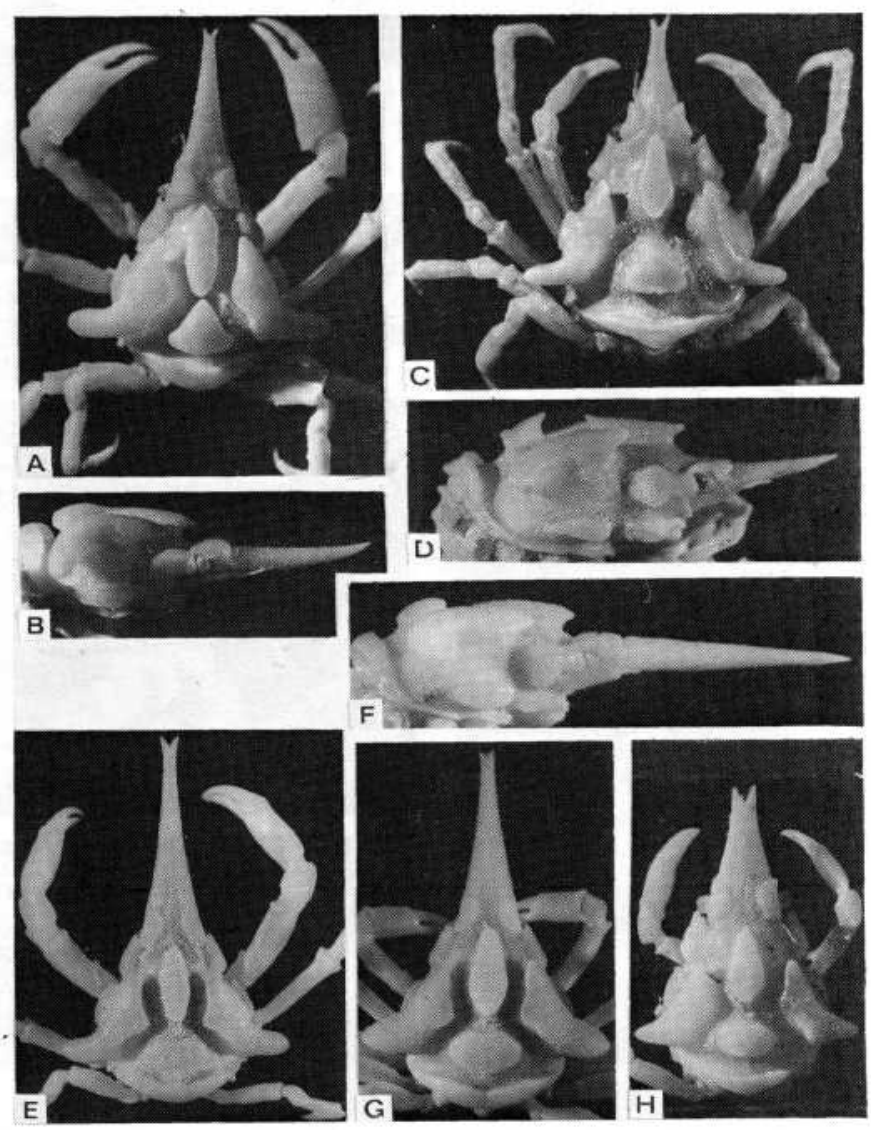




\section{GUINOT AND B. RICHER DE FORGES}

\section{Plate II}

Figure A-C. Sphenocarcinus pinocchio sp. nov., holotype and paratype, Makassar Strait, sta. $267,186-134 \mathrm{~m}$.

A-B, holotype, of $38 \times 15.5 \mathrm{~mm}$ (MP-B8749): A, entire animal, with, in the cornier on the left, the chelar propodus B, side face (a balanid is attached on the rostrum).

C-D, paratype, ovigerous $\& 19.5 \times 11.5 \mathrm{~mm}(\mathrm{MP}-\mathrm{B} 8750): \mathrm{C}$, carapace; $\mathrm{D}$, side face with the rostrum curved but weakly (rostrum only: $23.5 \mathrm{~mm}$ ).

Figure E-F. ? Sphenocarcinus pinocchio sp. nov., ? abnormal specimen, Makassar Strait, sta. $273,200-120 \mathrm{~m}$, of with a sacculinid parasite, $17 \times 15 \mathrm{~mm}$ (several balands are attached on the carapace) (MP-B8751): E. entire animal; F. side face: we can observe the very curved, "turnedup" rostrum (rostrum only: about $15 \mathrm{~mm}$ ).
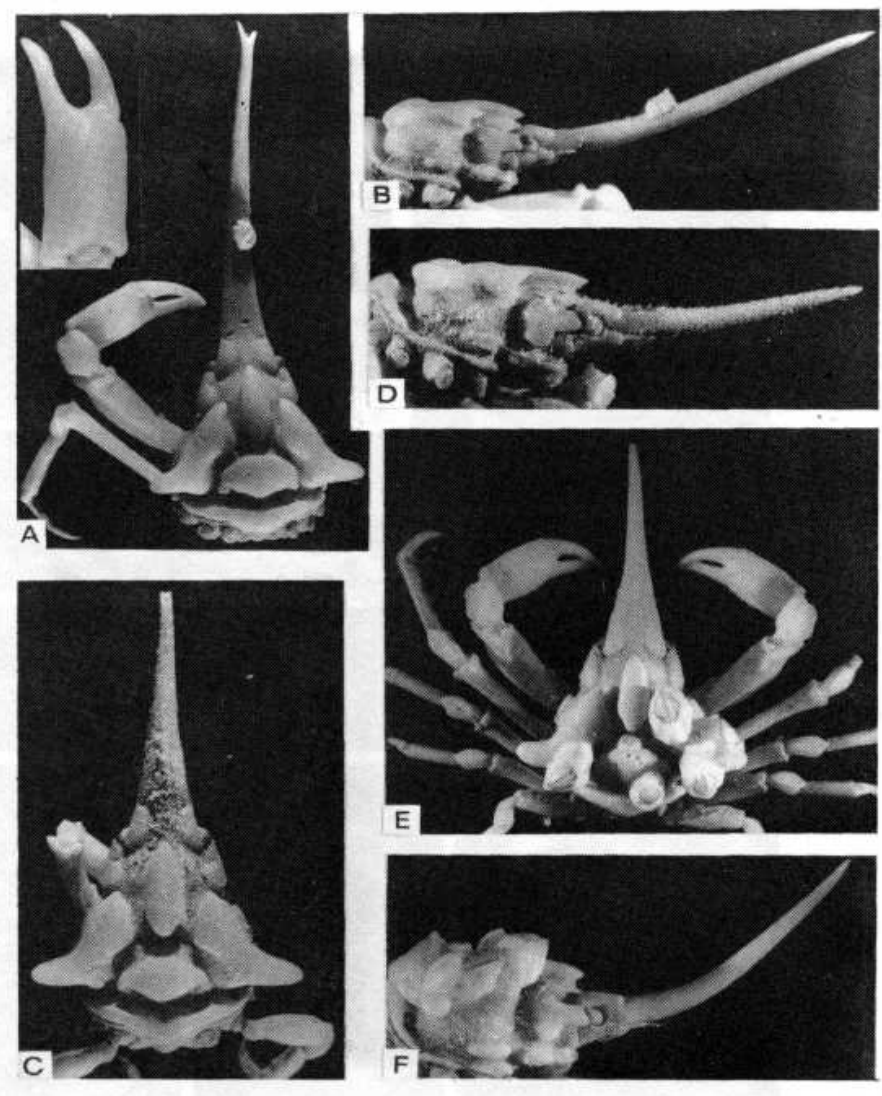


\title{
THE INDO-PACIFIC SPHENOCARCINUS
}

\begin{abstract}
ADDENDUM
After this manuscript went to the printer, Dr. M. K. Moosa forwarded to us representative of two other samples of Sphenocarcinus with a single rostrum from the Moluccas Archipelago, off Halmahera Island, Corindon IV.

1) Corindom IV, sta. COP. V/1, $03^{\circ} 28,8^{\prime} \mathrm{N}-128^{\circ} 23^{\prime} \mathrm{E}, 14-4-1981$ : 2 ㅇ ovigerous $25 \times 18 \mathrm{~mm}$ (rostrum broken), 19 x $13 \mathrm{~mm}, 1$ ㅇ sacculinized 22 × $15 \mathrm{~mm}$ (MP-B9488).

These three femaje individuals are near of $S$. pinocchio but principally differ by the shape of the cardiac plate more transversajly elongate and with smaller postero-lateral expansions. The rostrum of the small female is similar to that of $S$. pinocchio ovigerous female of analogous size $19,5 \times 11.5 \mathrm{~mm}$ ( $c f$. PI. II fig. C-D); the rostrum of the larger female is more widened at its baae and is distally broken. The sacculinized female has a very short and wide rostrum.

2) Corindon IV, sta. COP. V/2, Bay of Piru, 15-4-1981: $120.5 \mathrm{x}$ $16.5 \mathrm{~mm}$ (MP-B9489).

This male presents a very short rostrum, a gastric plate very narrow and elongate, a cardiac plate with horizontal expansions. These characters are different from those of all another species.
\end{abstract}

